\title{
Early China
}

\author{
EDITORS \\ Jeffrey K. Riegel William G. Boltz
}

ASSOCIATE EDITORS

\begin{abstract}
David N. Keightley Nancy Thompson Price
University of California, Davis, California Berkeley
\end{abstract}

\author{
ADVISORY BOARD
}

Barry B. Blakeley
Setcn Hail University
Gilbert L. Mattos
Foreign Broadcast
Information Service
Washington, D. C.
Robert Somers
University of Missouri-
Columbia

\author{
John S. Ciksoki \\ University of California, \\ Berkeley \\ Stanley L. Mickel \\ Wittenberg University
}

Richard B. Stamps

Oakland University
Cho-yun Hsu

University of Pittsburgh

Sydney Rosen

San Francisco, California

Ken-ichi Takashima

University of British Columbia 
The subscription rate is $\$ 6.00$ a copy for Early China 1. The rate is $\$ 7.00$ a copy for Early China 2, Early China 3, Early China 4, and Early China 5. Please add an additional $\$ 1.00$ to the rates for overseas subscribers. Checks should be made payable to: The Society for the Study of Early China, c/o David N. Keightley, Department of History, Berkeley, CA 94720
Early China is published annually by The Society for the Study of Early China (Chairperson: David N. Keightley, Secretary-Treasurer: Nancy Price). The Society and The Editors assume no responsibility for the views expressed by the: authors in The Society's publications.

\footnotetext{
The cover background is taken from the 1640 edition of the Shih chi, chllan 6.30b. It includes Ssu-ma Ch'ien's observation that those who do not forget the past are the masters of the future.

Cover design: Robert A. Eustachy
} 